Külgazdaság, LXIII. évf., 2019. szeptember-október (39-64. o.)

\title{
Adalékok a külföldi vállalatok magyarországi szerepének a megítéléséhez PALÓCZ ÉVA
}

A magyar gazdaság strukturális problémáit és alacsony termelékenységét nemcsak politikusok, hanem gyakran gazdasági elemzök is azzal (is) magyarázzák, hogy a multinacionális vállalatok alacsony hozzáadott értéket létrehozó tevékenységeket hoznak a magyar gazdaságba, ami csak az alacsony bérek nyújtotta elönyök kihasználására irányul. Azaz: Magyarország „összeszerelő üzemmé” vált. Ez az elemzés ezt az állitást árnyalja, bemutatva, hogy éppen ezek az „összeszerelö üzemek” járultak hozzá döntö mértékben a magyar makrogazdasági indikátorok (termelés, foglalkoztatás, bérszint) javulásához a vizsgált, 2008-2016 közötti időszakban. A külföldi tulajdonú vállalatok a magyar vállalati szektor által megtermelt összes hozzáadott érték több mint felét és a magyar GDP körülbelül 30 százalékát állítják elö, és a részarányuk folyamatosan növekszik. Ez a legmagasabb arány az EU-tagországok között, bár szerepük a többi visegrádi országban is viszonylag magas - és az utóbbi években tovább növekedett. A külföldi vállalatok termelékenysége Magyarországon a belföldi vállalati átlag háromszorosa, átlagos bérköltségük pedig a belföldi vállalatok 2,4-szerese. Ennél is fontosabb, hogy a magyar bérfelzárkózáshoz 2008 és 2016 között kizárólag a külföldi tulajdonú vállalatok járultak hozzá.*

Journal of Economic Literature (JEL) kód: F2, O1.

Bevezetés

A külföldi tulajdonú vállalatoknak a befogadó országokban betöltött szerepéröl számos tanulmány szólt az elmúlt évtizedekben. A vizsgálatok célkeresztjében az úgynevezett spillover, azaz tovagyürüző hatás áll, nevezetesen az, hogy milyen hatást

* Ez a cikk az OTKA K 125125 jelü, A termelési hálózatok jelentősége a globális versenyképesség tükrében - a magyar vállalatok integrálódása szempontjából elnevezésủ projekt keretében készült https://doi.org/10.47630/KULG.2019.63.9-10.39.

Palócz Éva, a Kopint-Tárki vezérigazgatója. E-mail: eva.palocz@kopint-tarki.hu 
gyakorolt a külföldi tőke jelenléte a befogadó országok teljesítményére, elsősorban a termelékenységére. Ez a tanulmány is ezekhez csatlakozik, tehát kifejezetten makrogazdasági statisztikai megközelítésủ, a külföldi vállalatok jelenlétének makrogazdasági hatásait elemzi. Nem foglalkozik a mikroszintủ vállalati okokkal és magatartásokkal, illetve a külföldi és a belföldi vállalatok közötti kölcsönhatásokkal sem. Az utóbbi kérdések más, többek között a Külgazdaság hasábjain megjelent cikkek témái voltak (például Antalóczy-Sass, 2003, Gál-Sass-Juhász, 2016, Szalavetz, 2017 és mások).

A külföldi tőke hatásának elemzésére alapvetően kétféle módszer kínálkozik. A spillover hatást a makroszintủ adatok alapján a nemzetközi irodalom a külföldi közvetlen tőkeberuházások (FDI) állományának és állományváltozásának, valamint a befogadó ország gazdasági teljesítményének az összehasonlításával vizsgálja. Bijsterbosch és Kolasa [2009] például nyolc kelet-közép-európai ország - a négy visegrádi ország (V4), Szlovénia, valamint a Baltikum - konvergenciáját elemezve azt állapította meg, hogy ezeknek az országoknak a termelékenységi szintje 1995 és 2005 között jelentősen emelkedett, ami nagyrészt a külföldi tőkebeáramlásnak köszönhető. Erre az eredményre pedig úgy jutottak, hogy az EU KLEMS ${ }^{1}$ kifejezetten kifinomult, munkaórára és vásárlóerő-paritáson számított aggregált nemzeti termelékenységi adatait összehasonlították a külföldi tőkeállomány nagyságával.

Bár ez a közvetett bizonyíték (az egyszerűség kedvéért tekintsük ennek) is helytálló lehet, azonban nem ad választ arra a kérdésre, hogy a befogadó országokban az aggregált termelékenység javulása vajon csak a külföldi vállalatok magas és az átlagos termelékenységet megemelő hatásának tulajdonítható-e, vagy a külföldi vállalatok kedvező hatással voltak a belföldi vállalatok termelékenységére is. Számos más tanulmány is ezzel a módszerrel élt, azaz a külföldi tőkeállomány hatását vizsgálta a befogadó országok gazdaságára (Borensztei-De Gregorio-Lee, 1995).

Ennek a módszernek - az említettek mellett - az is a korlátja, hogy az FDIállományok mérését számos bizonytalanság övezi (lásd: Antalóczy-Sass, 2014). Ráadásul az FDI-állomány mérésének a célja alapjában véve más: a nemzetközi pénzügyi áramlások irányának a megjelenítését és nem a tőke müködésének a hatását célozza, ezért nem igazán alkalmas a belföldi hatások pontos mérésére. Az újrabefektetett jövedelem bonyolult számítása pedig reálgazdasági értelemben akár téves következtetések levonására is vezethet (Oblath, 2017). (A spillover hatás FDIállománnyal való összehasonlításának részletes kritikáját lásd: Lipsey, 2006.)

${ }^{1}$ Az EU KLEMS az Európai Unió ipari szintủ növekedési és termelékenységi projektje, a betűszó átöleli a lényegét: capital (K), labour (L), energy (E), materials (M) and service (S) inputs. 
A másik módszer a mikroszintủ vállalati adatok alapján vizsgálja a külföldi tőkebeáramlás hatását a vállalati szektor teljesítményének az alakulására. Ezt nehezíti, hogy teljes körü, valamennyi ágazatot és jelentős mennyiségủ elemi vállalati adatot tartalmazó nemzetközi adatbázisok nem igazán álltak rendelkezésre. Vannak ugyan vállalati adatokat tartalmazó, megvásárolható nemzetközi adatbázisok, ezek azonban jellemzően nem tartalmazzák a gazdaságok teljes vállalati körét, jelesül a mikro- és kisvállalatokat. Ezért a legtöbb tanulmány egy-egy országra vagy egy-egy kiragadott ágazatra vonatkozó parciális vizsgálatokat végzett, például Javorcik [2004] a litván vállalati adatbázis alapján vagy Pavlínek [2015] a külföldi tőke hatásáról a kelet-közép-európai autóiparra. Más tanulmányok vállalati felméréseket használtak, mint például Gorodnichenko-Svejnar-Terrel [2007] az Európai Újjáépítési és Fejlesztési Bank, valamint a Világbank Business Environment and Enterprise Performance Surveys (BEEPS) adatait. Ez az elemzés az utóbbi megközelítési módot alkalmazza, ehhez az Eurostat SBS² adatbázisában közölt vállalatcsoportos adatokat használja fel. Mivel nem elemi, mikroszintű vállalati adatokról van szó, hanem ezekből képzett vállalatcsoportos mutatókról, ezért ezeket mezzostatisztikának nevezzük.

Az első fejezet az SBS-adatbázist mutatja be, a második a külföldi vállalatok súlyát elemzi a vállalati szektor által termelt hozzáadott értékben és a GDP-ben. A harmadik fejezet a külföldi vállalatok részesedését vizsgálja a foglalkoztatás és a bérszintek változásában, valamint számításokat végez a külföldi vállalatok szerepéről a magyar (és a V4-ek) bérfelzárkózására vonatkozóan. A negyedik fejezet a külföldi cégeknek a befogadó országok átlagos vállalati termelékenységének alakulásában betöltött szerepét elemzi. Az ötödik fejezetben összefoglaljuk a vizsgált jelenségekből levonható következtetéseket. Noha elsősorban a hazai helyzetre koncentrálunk, Magyarország pozícióját az EU-tagországok csoportjába ágyazva vizsgáljuk, különös tekintettel a kelet-közép-európai régióra és a V4 országokra.

\section{A tanulmány statisztikai háttere}

Az elmúlt két évtizedben a belföldi és a nemzetközi statisztikai szervezetek is egyre nagyobb hangsúlyt helyeztek a gazdaságok vállalati szerkezetére és a vállalati teljesítményadatokra vonatkozó szisztematikus és átfogó adatgyüjtésre, kiegészítve

2 Az SBS a Structural business statistics rövidítése, amely több száz szektorban különböző szempontok szerint összeállított vállalatcsoportos bontásban (vállalati méret, tulajdonosi szerkezet, növekedési ütem stb.) részletezi a gazdasági tevékenység szerkezetét, versenyképességét és teljesítményét. 
ezzel az alapvetően makrostatisztikai jellegű adatgyüjtéseket. Ez a makrogazdasági folyamatok jobb megértését és magyarázatát szolgálja a vállalati szektorban, azaz a mikroszférában zajló folyamatok vizsgálhatóságának a segítségével. Az Eurostat az SBS-adatgyüjtés keretében már körülbelül másfél évtizede publikál tulajdonosi bontásban vállalatcsoportos mutatókat. Külföldi társaságnak (foreign controlled company) a nemzetközi szokásoknak megfelelően azt tekinti, amelyik 50 százaléknál magasabb külföldi tőkearánnyal működik. Ez a statisztika körülbelül tíz, a vállalati eredménykimutatásokon alapuló primer és további tíz származtatott, számított adatot közöl ágazati és szakágazati szinten (két számjegyü bontásban).

Mivel az Eurostat SBS viszonylag új adatgyüjtésen alapul, nem annyira kiforrott és teljes, mint a föbb makrostatisztikák, ezért ezt a korlátot az adatok értékelésekor figyelembe kell venni:

- Az idősor viszonylag rövid, a 2008-2016 közötti időszakra terjed ki. Létezik ugyan egy 2003-2007 (2008) közötti adatbázis, a két statisztika között azonban nemcsak a TEÁOR-változásokból következően van törés az ágazati adatokban. A váltást jelentő 2008-as évben, amely mindkét statisztikában fellelhetö, az aggregált adatok sem teljesen egyeznek, így a két idősor összekapcsolásával kockázatos lenne 2003-2016 közötti idősort készíteni.

- A vállalati adatok euróban vannak kifejezve, ami érzékennyé teszi őket mind az árfolyam, mind az árszint változására. Vásárlóerő-paritásos adatok nincsenek. Ez súlyos hiányosság lenne, ha az országok közötti különbségeket vizsgálnánk. Elemzésünk azonban az egyes országokon belül a külföldi vállalatok részesedését, főbb mutatóinak a nemzetgazdasági átlagokkal és a hazai vállalatokkal való összehasonlítását célozza. Ezért az euróban megadott adatok nem torzítanak, mivel egy adott gazdaságon belül az árfolyam- és árszinthatások a külföldi és a belföldi tulajdonú vállalatokat egyformán érintik.

- Bár az SBS adatkezelése folyamatosan javul, ami az adatbázis tartalmának folyamatos nyomon követésével az elmúlt években megállapítható volt, még mindig előfordulnak kiugró és értelmezhetetlen értékek, amelyek az adattisztítás hiányosságaira utalnak. Csak egy példa: 2016-ban Írországban a külföldi vállalatok által foglalkoztatottak száma az előző években mértnek kevesebb mint felére esett vissza, ami feltehetően valamelyik gigavállalat számviteli manőveréhez köthető. Ezért a vizsgált adatokat igyekeztünk megtisztítani - ahol ez lehetséges volt - a kiugró (outlayer) adatoktól, és a kilencéves idősor trendjébe simítani. Ahol pedig ez nem volt lehetséges, ott az extrém adatokat és ingadozásokat produkáló országokat kihagytuk az elemzésből. Ez az oka annak, hogy 
Írország, Luxemburg, Ciprus és Málta az elemzésben nem szerepel, és egyes alfejezetekben más országok is hiányoznak, amelyek adatai inkonzisztensek és erősen ingadozóak voltak. Az EU-28 adatát ennek megfelelően átszámítottuk annyi országra, amennyi az adatsorban található. Ez azért volt lehetséges, mert az alapadatok euróban (és föben) vannak megadva. Emellett Szlovákia esetében a 2008. évi adat helyett a 2010. évi adatot, Németország esetében pedig a 2016. évi adat helyett a 2015. évi adatot használtuk. ${ }^{3}$

- A vállalati szintủ adatok felhasználásával szemben gyakran fel szokták vetni, hogy a multinacionális vállalatok transzferárazása torzítja a termelésre (következésképpen: a hozzáadott értékre) és a vállalati pénzügyi eredményre vonatkozó adatokat. Ez valós jelenség: a multinacionális vállalatok gyakran élnek azzal a lehetőséggel, hogy a transzferárazás segítségével a nyereséget egy tetszőleges országba allokálják (lásd: OECD, 2019). Ez lehet az anyavállalat országa, vagy valamely más, kedvező adózású ország. Ilyesmiről lehet szó a már említett ír példa esetében is. Megítélésünk szerint azonban mindez nem okoz olyan mértékü torzitást, amely a számítások eredményeit megkérdőjelezné.

A fenntartások akkurátus figyelembevétele mellett is megállapítható, hogy a statisztikákból - mint látni fogjuk - olyan robusztus folyamatok rajzolódnak ki, amelyek az esetleges módszertani bizonytalanságok mellett is (amelyek korántsem csak ennek az adatforrásnak a sajátjai) alkalmasak arra, hogy belölük megalapozott következtetéseket vonjunk le.

A vizsgált vállalati kör kizárólag a versenyszektorba tartozó, nem pénzügyi vállalatok csoportja, tehát a továbbiakban vállalatok alatt minden esetben nem pénzügyi vállalatokat kell érteni.

\section{A külföldi nem pénzügyi vállalatok súlya a termelésben}

\section{Részesedés a hozzáadottérték-termelésben}

Az 1. ábra az Európai Unió 24 országában az EU-n belüli és kívüli országokból származó külföldi vállalatok által elóállított (tényezőköltségen számított) hozzáadott érték részesedését mutatja a teljes vállalati szektorban. Mint látható, az első hét helyen kelet-közép-európai országok állnak, ezen belül az első négy helyen a V4 közül

${ }^{3}$ Az Eurostat SBS adatai szerint 2010-ben a szlovák vállalati szektorban foglalkoztatottak száma 465 ezer fővel (46 százalékkal!) emelkedett az elöző két évhez képest. Ez olyan módszertani változtatásra utal, amely az idősoros összehasonlításra a 2008-2009. évi adatokat alkalmazhatatlanná teszi. Németországban pedig a 2016. évi adat tér el nagymértékben az idősor egyéb adataitól. 
három ország és Románia, 44-51 százalék közötti részaránnyal. Az utóbbi, legmagasabb értéket Magyarország mutatja.

1. ábra

\section{A külföldi tulajdonú vállalatok részesedése a teljes vállalati szektor által előállított hozzáadott értékben 2008-ban és 2016-ban}

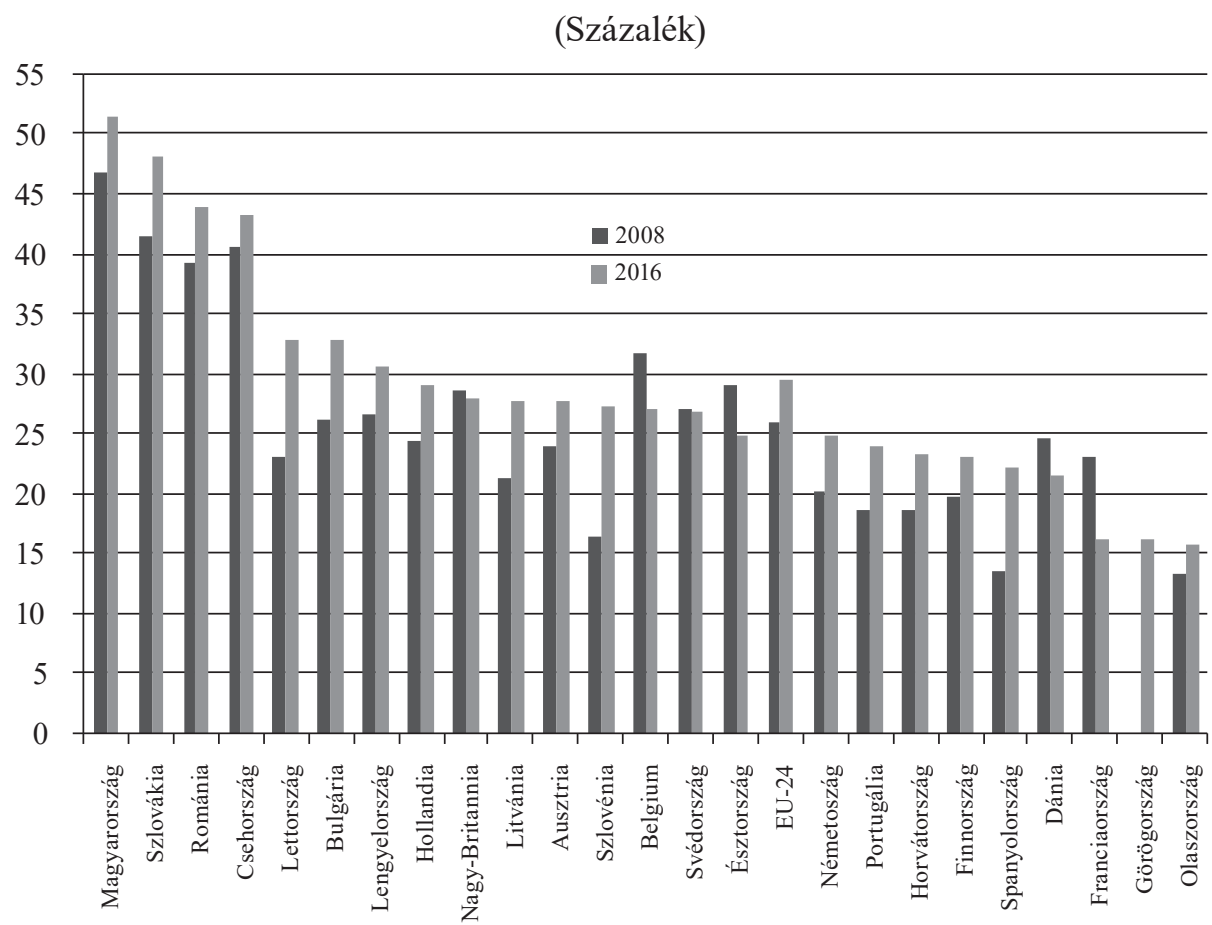

Forrás: Saját számítások az Eurostat Structural Business Statistics alapján. Dániára a kiugró 2008. évi adat helyett 2009. évi adat szerepel (lásd: https:/ec.europa.eu/eurostat/data/database).

A magyar gazdaságban a külföldi tőke részaránya a hozzáadottérték-termelésben már 2008-ban is a legmagasabb (47 százalék) volt az EU-ban, 2011 óta pedig a vállalati szektor hozzáadott értékének több mint felét a külföldi tulajdonú vállalatok állitják elő. Részesedésük 2008 és 2016 között 4 százalékponttal emelkedett. Szlovákia szorosan követi Magyarországot 48 százalék körüli részesedéssel, itt 5 százalékpontos volt a részarány-növekedés a vizsgált időszakban. Még a kifejezetten erős hazai vállalati szektorral és nagy belföldi piaccal rendelkező Lengyelországban is 30 szá- 
zalék fölé emelkedett 2016-ra a külföldi vállalatok részaránya a vállalati hozzáadott érték termelésében (a 2008. évi 27 százalékról).

A kelet-közép-európai országokban a külföldi vállalatok magas aránya a vállalati hozzáadott érték előállításában jórészt az 1990-es években történt privatizációs folyamat módjával magyarázható. Ezt - különböző mértékben ugyan, de minden országban - a külföldi vállalatok bevonása jellemezte. Ezek ismert tények, amelyeket számos tanulmány részletesen elemzett, csak néhányat említve: Kalotay-Hunya [2000], Mihályi [1998] és [2010], Voszka [1996], Sinn-Weichenrieder [1997]. Az azonban figyelemre méltó, hogy a kelet-közép-európai országokban a külföldi vállalatok részaránya a vizsgált időszakban, 2008 és 2016 között is számottevően, 5-10 százalékponttal emelkedett, ami arra utal, hogy a 2010-es években is gyorsabban nőtt a külföldi vállalatok teljesítménye, mint a hazaiaké. Ez részben a már letelepedett külföldi vállalatok termelésbővülésével, részben új müködőtőke-beruházásokkal magyarázható. Mindez összhangban van azzal a gazdaságstratégiával, amely jelentős mértékben épít a külföldi tőke bevonására. Szlovéniában emellett a megkésett privatizáció hatásaként 2008-2016 között 11 százalékponttal, 16-ról 27 százalékra emelkedett a külföldi társaságok aránya a vállalati teljesítményekben. Lettországban 10, Bulgáriában 8 százalékponttal nőtt a külföldi tulajdonú vállalatok részesedése a hozzáadott érték termelésében.

A külföldi tőke szerepének erősödése korántsem csak kelet-közép-európai sajátosság, a többi EU-tagországban is megfigyelhető: 2008 és 2016 között a külföldi tőke aránya a belföldi versenyszektorban megtermelt hozzáadott értékben az EU24 átlagában 23-ról 25 százalékra emelkedett. A vizsgált 24 uniós tagország között mindössze három olyan található, amelyben a külföldi vállalatok részesedése számottevően csökkent (Dánia, Belgium és Franciaország), és egy, amelyben csak kissé mérséklődött (Észtország). Az aránycsökkenés mind a négy országban úgy következett be, hogy a külföldi vállalatok által termelt hozzáadott érték 2008-2016 között folyó áron, euróban kifejezve nagyjából stagnált (reálértékben tehát csökkent), miközben a hazai tulajdonúaké számottevően nőtt (Észtországban különösen gyorsan).

A külföldi tulajdonú vállalatok részarányának növekedése az EU-tagországok versenyszektorának teljesítményében fontos adalék a külföldi tőke szerepének a megítéléséhez az elmúlt tíz évben. A külföldi vállalatok részesedése a hozzáadott értékben legalábbis 2016-ig az EU legtöbb országában majdnem töretlenül nőtt (a fent felsorolt négy ország kivételével), csupán a növekedés mértéke különbözött. Ezek a vállalati mezzoadatok ellentmondanak azoknak a makroszintü adatok alap- 
ján megfogalmazott állitásoknak, melyek szerint a külföldi tőkeberuházások dinamikája alábbhagyni látszana.

A „külföldi tőke” penetrációja nem kizárólag a globális multinacionális vállalatok terjeszkedését jelenti. Az EU-n belül a piaci integráció erősödése következtében számottevően nő a határokat átlépő, a belföldi piac mellett más tagországokban terjeszkedő kis-, közép- és (nem globális) nagyvállalatok száma és jelentősége is.

Becsült részesedés a GDP-ben

Az alábbiakban arra teszünk kísérletet, hogy megbecsüljük, hogyan alakult az adott időszakban az egyes országokban a külföldi vállalatok hozzáadott értékének a súlya a GDP-ben. Elöljáróban hangsúlyozni kell, hogy a vállalati adatokra épülő mezzostatisztikai adatok csak korlátozottan feleltethetők meg a makroszintủ statisztika adatoknak, mivel az alulról számított, mikroadatok aggregálásából származó vállalati hozzáadott érték és a felülről számított, a nemzeti számlák rendszerébe beágyazott GDP eltérő módszerrel és más szemléletben készül. A GDP számításakor a statisztikusok az aggregált vállalati hozzáadottérték-adatokból indulnak ki ugyan, de azok még számos korrekción és a más számlákkal való egyeztetésen mennek keresztül, amíg azokból nemzetgazdasági szintű hozzáadott érték lesz. Ezeket a szempontokat a számítások során igyekeztünk figyelembe venni.

Az SBS adatbázisban a vállalatok hozzáadottérték-termelése tényezököltségen (factor cost), euróban kifejezve áll rendelkezésre. A GDP-vel való összehasonlításhoz ezért szintén a tényezőköltségen számított GDP-t kell figyelembe venni, amely a piaci áron mért GDP-ből a termelési és importadók és támogatások egyenlegének levonásával számítható ki.

1. képlet

$$
V A_{F / T}^{f c}=\frac{V A_{F}^{f c}}{G D P^{m p}-N T P I}
$$

\section{Ahol}

$V A_{F / T}^{f c}$ a külföldi nem pénzügyi vállalatok hozzáadott értékének részaránya a tényezőköltségen mért GDP-ben,

$V A_{F}^{f c}$ : a külföldi nem pénzügyi vállalatok hozzáadott értéke, tényezőköltségen, $G D P^{m p}$ : GDP piaci áron (market prices),

NTPI: a termelési és importadók és a termelési támogatások egyenlege, $G D P^{m p}-N T P I$ : GDP tényezököltségen. 
Az 1. képlet tehát a külföldi vállalatok által megtermelt hozzáadott érték és a GDP hányadosa, mindkettő tényezőáron mérve. A számítások eredményeit, azaz a külföldi vállalatok részesedését a tényezőáron mért GDP-ből a 2. ábra tartalmazza.

\section{A külföldi vállalatok becsült részesedése a vizsgált országok GDP-jében}

(Százalék)

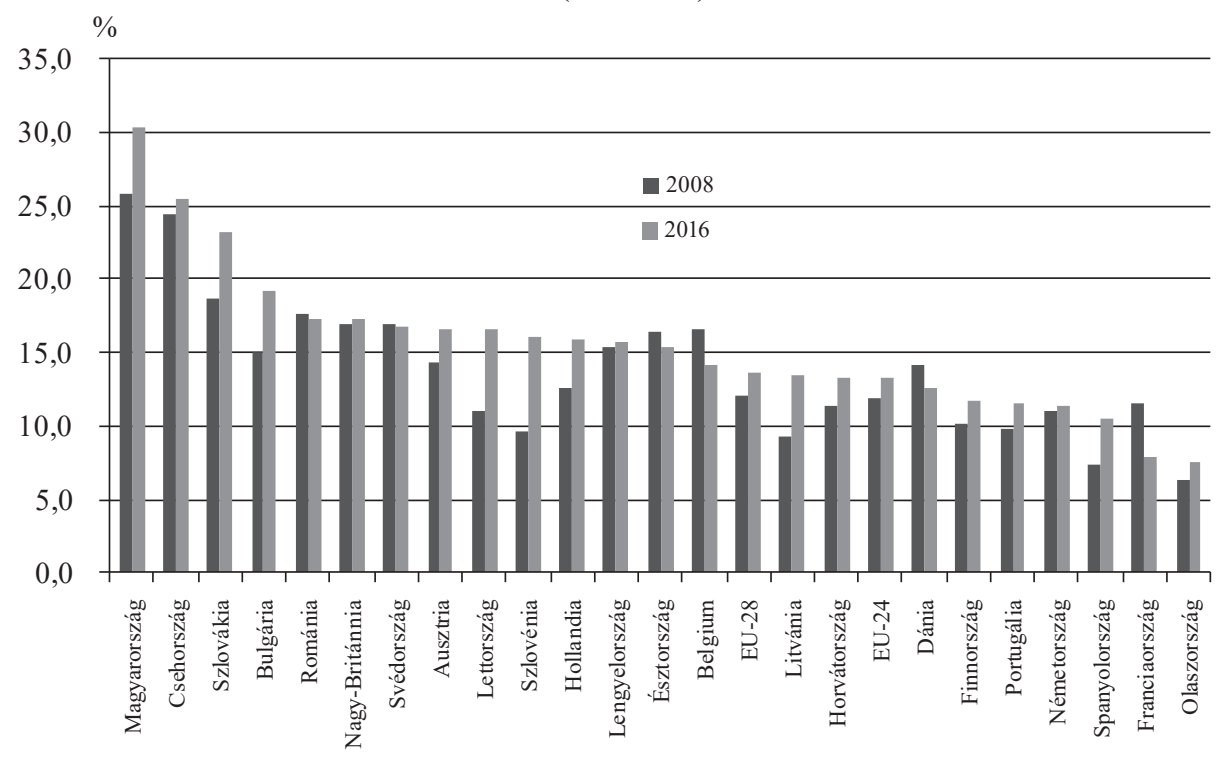

Forrás: Saját számítások az Eurostat SBS és Economy and Finance adatbázisa alapján.

Mint a 2. ábra jelzi, a GDP-ben való részesedés tekintetében is Magyarország áll az élen: 2016-ban a külföldi tulajdonú vállalatok a teljes magyar GDP 30 százalékát állították elő, részesedésük 2008 és 2016 között mintegy 5 százalékponttal emelkedett. Hasonló mértékủ emelkedés történt Szlovákiában, 18-ról 23 százalékra. Csehországban csupán 24-ről 25 százalékra emelkedett, Romániában változatlanul 17 százalék, Lengyelországban 15,5 százalék volt a külföldi vállalatok részaránya a GDP-ben. A külföldi vállalatok részaránya a GDP-ben a legtöbb EU-országban emelkedett 2008-2016 között, aminek következtében az EU-24 átlaga is nőtt, majdnem 2 százalékponttal. 
A GDP-ben betöltött részesedés mérésének másik becslési módszere, amelyet inkább ellenörzés céljára használtunk, az Európai Bizottság makroökonómiai adatbázisának, az AMECO-nak a vállalati szektor által megtermelt (UGVAC kódjelü) hozzáadottérték-adatsorából indul ki. Ezt az adatsort összehasonlítva a szintén tényezőáron számított GDP-vel, megkapjuk a vállalati szektor részesedését a GDPben. Az EU-országokban ez az arány jellemzően 55-70 százalék között ingadozik, de vannak extrém értékek is: Görögországban például 44 százalék, Svédországban pedig 80 százalék volt 2016-ban. Magyarországon és Csehországban ez az arány 2016-ban a GDP 65 százaléka, Romániában 62, Lengyelországban és Szlovákiában 55 százalék körüli volt. A vállalati szektor e részaránymutatója azután rávetíthető az 1. ábrán bemutatott arányokra, azaz a külföldi cégek hozzáadott értékének az arányára a teljes vállalati szektoron belül. Az AMECO vállalati hozzáadottértékadatsora sajnos összevontan tartalmazza a nem pénzügyi (S11) és a pénzügyi (S12) vállalatok adatait, ezért a végeredményt is felülbecsüli. Magyarország esetében ezzel a módszerrel 33 százalék jön ki a külföldi vállalatok GDP-ben betöltött részarányára, ami a pénzügyi vállalatok torzító hatásából ered. Összességében azonban az ellenőrzés az eredeti számítás helyességét támasztja alá.

\section{A külföldi nem pénzügyi vállalatok súlya a foglalkoztatás és a bérek} változásában

Foglalkoztatás

Nemcsak a hozzáadottérték-termelésben, hanem a foglalkoztatásban is folyamatosan emelkedik a külföldi vállalatok súlya az EU-tagországokban. A V4 országokban és Romániában a teljes vállalati szektor 45-51 százalékát kitevő hozzáadott értékét (lásd az 1. ábrát) a külföldi vállalatok a versenyszektorban foglalkoztatottak 25-30 százalékával állították elő 2016-ban (lásd a 3. ábrát).

Az adatok részletes vizsgálata azt mutatja, hogy 2009-ben a válságra a külföldi vállalatok ugyanúgy elbocsátásokkal reagáltak, mint a belföldiek (EU-szinten a külföldi cégeknél foglalkoztatottak száma 2009-ben 6, a belföldieknél 3 százalékkal csökkent). A válságot követő években azonban a külföldiek sokkal hamarabb állították helyre a válság előtti létszámot: EU-szinten összesítve 2012-ben már több alkalmazottat foglalkoztattak, mint a válság előtt, sőt több országban ez már korábban bekövetkezett. Ezt követően pedig gyorsan emelkedett a létszám, ami összhangban volt a hozzáadott értéknek az 1. ábrán bemutatott növekedésével is. A belföldi cé- 
gek által foglalkoztatottak létszáma EU-szinten ugyanakkor csak 2016-ra állt helyre, illetve haladta meg a 2008. évi szintet. A munkahelyvesztés tehát a belföldi cégek esetében sokkal tartósabbnak bizonyult.

\section{A külföldi cégek által foglalkoztatottak létszámának az aránya a teljes vállalati szektorban (nem pénzügyi vállalatok), 2008-ban és 2016-ban}

(Százalék)

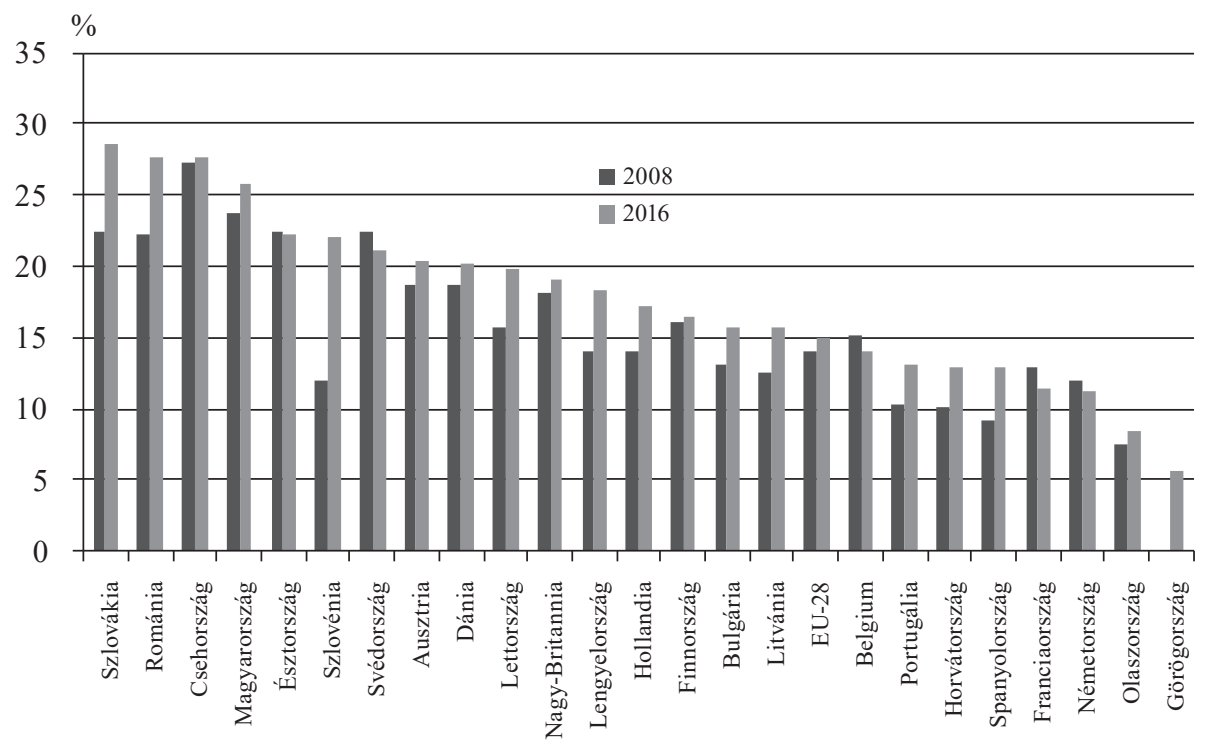

Forrás: Saját számítások az Eurostat Structural Business Statistics alapján.

Ezzel az EU-országok többségében figyelemre méltó eltolódás következett be a foglalkoztatásban, a belföldi tulajdonú vállalatoktól a külföldiek javára, amit a 4 . ábra még szemléletesebben mutat be. A 22 ország közül 13-ban a belföldi tulajdonú vállalatok kevesebb fôt foglalkoztattak 2016-ban, mint a válság előtt, miközben a külföldi vállalatok létszáma emelkedett. A külföldi cégeknél foglalkoztatottak száma csupán két országban, Franciaországban és Észtországban csökkent a vizsgált időszakban, 5 , illetve 10 százalékkal. 


\section{A külföldi és a helyi tulajdonú vállalatok által foglalkoztatottak létszámának} százalékos változása 2008-2016 között

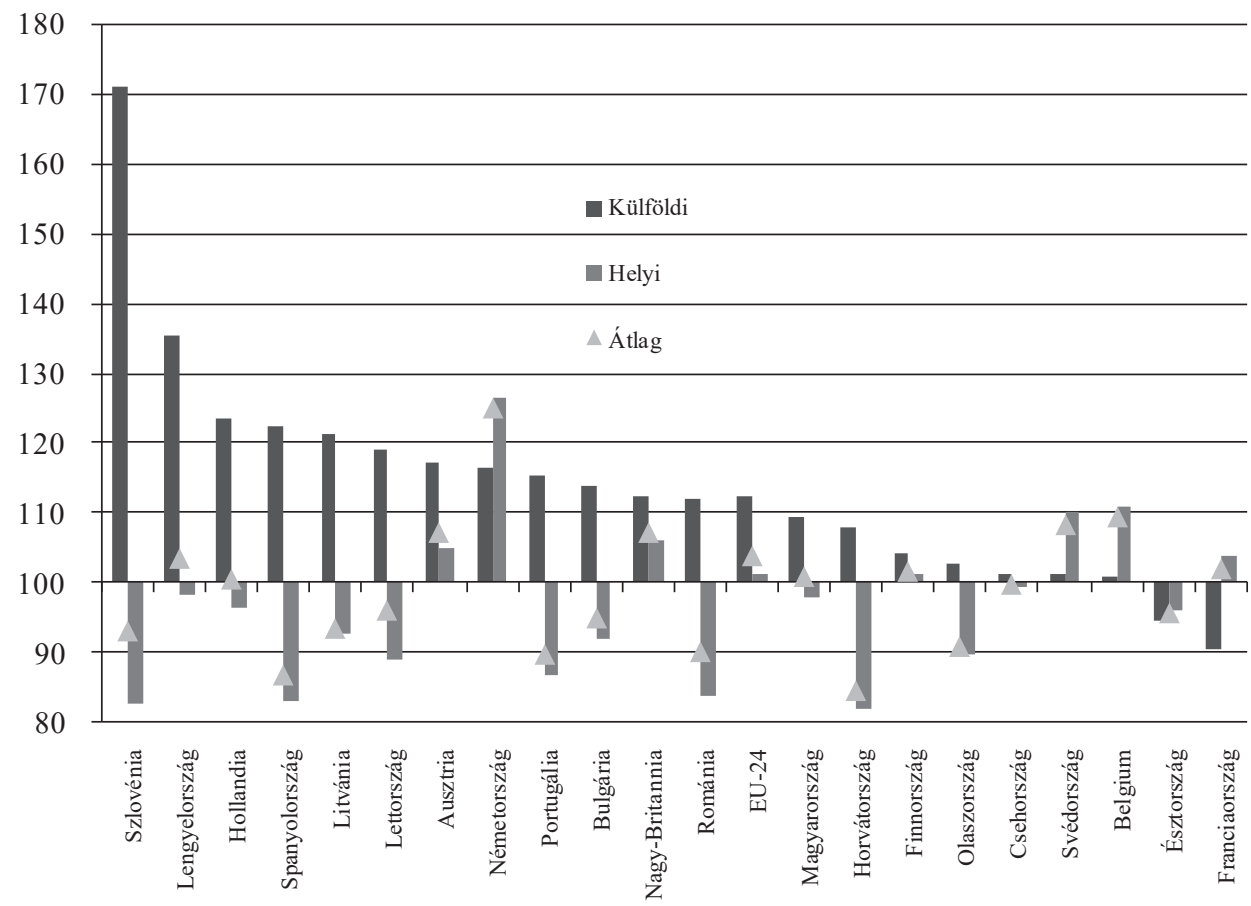

Forrás: Saját számítások az Eurostat Structural Business Statistics alapján.

A kelet-közép-európai országok közül különösen nagy volt a külföldi cégek létszámnövekedése Szlovéniában és Lengyelországban. Magyarországon és Csehországban nem történt jelentős eltolódás a foglalkoztatási szerkezetben a külföldi és a belföldi cégek között.

Bérek

A külföldi tulajdonú vállalatok bérszínvonala valamennyi EU-tagországban meghaladja a nemzetgazdasági átlagot. Ez a magasabb termelékenységgel áll kapcsolatban, amelyet a következö fejezetben tekintünk át. Pontosabban: az SBS a vállalati „személyi költség” (personel cost) adatokat mutatja, amely a bruttó béreken felül a munkáltatók által fizetett bérjárulékokat és egyéb személyi költségeket is tar- 
talmazza. A munkáltatók által fizetett bérköltség nagysága tehát a járulékkulcsok változásától is függ, ez azonban mind a külföldi, mind a belföldi vállalatok számára egységesen érvényes, tehát az országokon belül különbségeket nem befolyásolja.

A külföldi tulajdonú vállalatok egy före jutó személyi költsége a teljes vállalati szektor átlagához képest

(Nemzetgazdasági vállalati átlag $=1)$

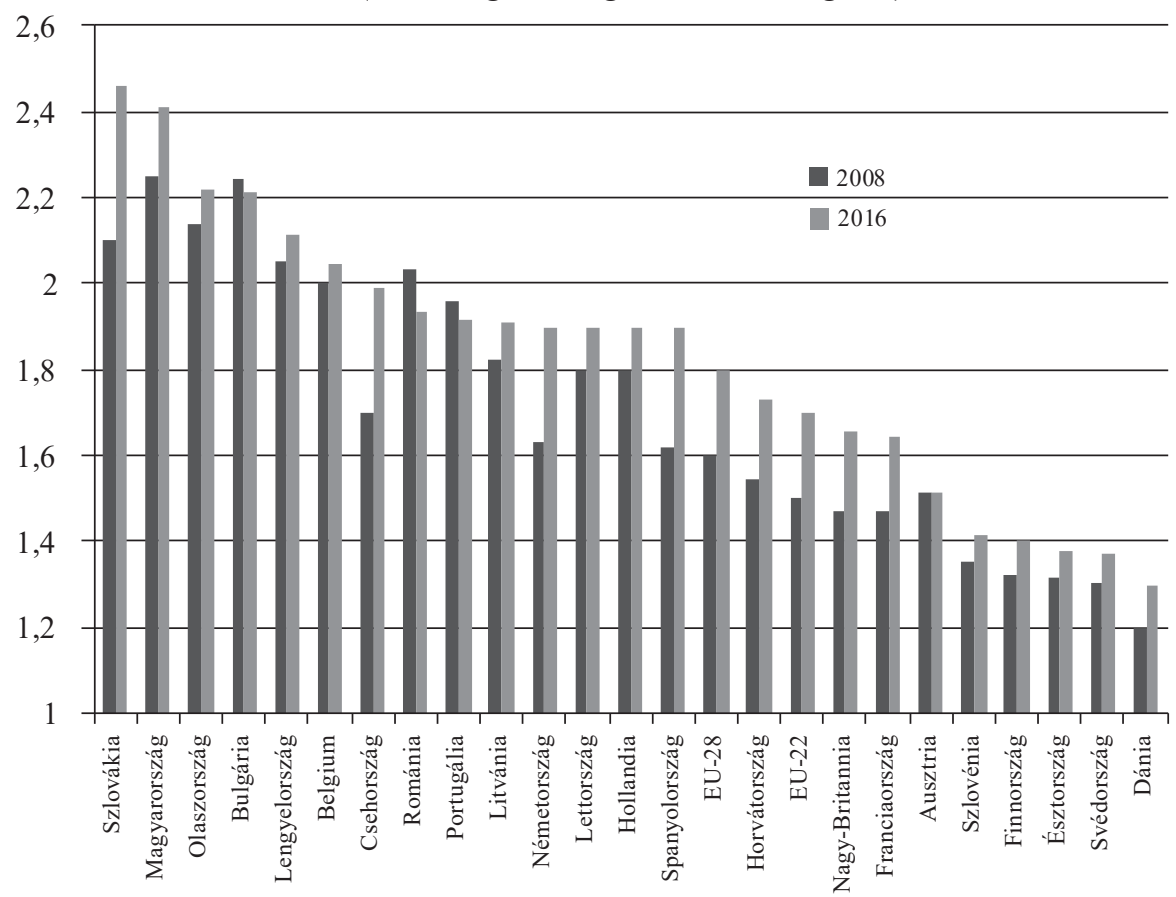

Forrás: Saját számítások az Eurostat Structural Business Statistics alapján.

Mint az 5. ábra mutatja, a külföldi vállalatok nemcsak magasabb béreket fizetnek, hanem a bérköltségelőnyük a teljes vállalati szektor átlagához képest még jócskán növekedett is 2008-2016 között. A vállalati szintủ átlagos bérszínvonalat tehát 2016-ban a külföldi vállalatok jelenléte három csatornán keresztül is befolyásolta. Egyrészt a már 2008-ban is magasabb bérszínvonal (5. ábra), másrészt az átlagosnál 
nagyobb béremelkedés, harmadrészt pedig a magasabb bért fizető külföldi vállalatok részarányának az emelkedése (összetétel-hatás).

Az 1. táblázat (1) oszlopa a külföldi vállalatok bérköltségszintjének a versenyszektor átlagához viszonyított százalékos eltérését mutatja 2008-ban, a (4) oszlop pedig ugyanezt, 2016-ban. Ezeket az adatokat már feltüntettük az 5. ábrán. A (2) és (3) oszlop a bérek emelkedését mutatja 2008-2016 között a külföldi vállalatokra (F) és a teljes versenyszektorra vonatkozóan. Az Eurostat euróban közli a bérköltségadatokat (is), ezek az eurózónán kívüli országokra - az árfolyamhatás miatt - nagyban eltérhetnek a nemzeti valutában számított értékektől. ${ }^{4}$ Mivel azonban a cikk célja nem a béremelkedés tényleges mértékének a vizsgálata, hanem az, hogy a bérszint változásához milyen mértékben járultak hozzá a külföldi tulajdonú vállalatok, az adatokat nem számítottuk át nemzeti valutára.

Az (5) és (6) oszlop a külföldi vállalatok által foglalkoztatottak részarányát mutatja a teljes versenyszektorban 2008-ban és 2016-ban, a 3. ábrán bemutatottaknak megfelelően.

1. táblázat

A külföldi vállalatok bérnövekedése és foglalkoztatási részaránya, 2008-2016

\begin{tabular}{lcccccc}
\hline & $(1)$ & $(2)$ & $(3)$ & $(4)$ & $(5)$ & $(6)$ \\
\hline & $\begin{array}{l}F \text { bér, 2008-ban } \\
\text { átlagbér = } 100\end{array}$ & $\begin{array}{c}\text { Béremelkedés euróban, } \\
2008-2016,2008=100\end{array}$ & $\begin{array}{c}F \text { bér, 2016-ban } \\
\text { átlagbér = 100 }\end{array}$ & $\begin{array}{c}F \text { részarány } \\
\text { a foglalkoztatásban, \% }\end{array}$ \\
\hline \multicolumn{7}{c}{} \\
& 2008 & $\mathrm{~F}$ & $\begin{array}{c}\text { Teljes verseny- } \\
\text { szektor }\end{array}$ & 2016 & 2008 & 2016 \\
\hline EU-24 & 147,8 & 121,2 & 111,6 & 160,6 & 13,9 & 15,0 \\
Bulgária & 193,0 & 161,4 & 167,6 & 185,9 & 13,1 & 15,7 \\
Csehország & 142,7 & 116,5 & 106,3 & 156,3 & 27,3 & 27,6 \\
Dánia & 113,1 & 114,0 & 104,0 & 124,1 & 29,7 & 20,1 \\
Németor- & 151,8 & 126,6 & 109,9 & 176,4 & 12,0 & 11,2 \\
szág* & & & & & &
\end{tabular}

${ }^{4}$ A magyar példa: ha az SBS euróban feltüntetett adatait forintra átszámítjuk, akkor az egy fơre jutó bérköltség a nem pénzügyi vállalati szektorban 2008-2016 között nem 7,7 százalékkal (1. táblázat (3) oszlop magyar sora), hanem 33,5 százalékkal emelkedett. A különbség oka az árfolyamváltozás. 2008-ban az éves átlagos euróárfolyam még 251,5 forint volt, 2016-ban pedig 311,4 forint. Érdemes megjegyezni, hogy a KSH adatai szerint a teljes vállalati szektorban foglalkoztatottak havi bruttó átlagkeresete 2008-2016 között 44 százalékkal emelkedett. Ez azonban szélesebb vállalati körre vonatkozik (pénzügyi vállalatokra is), és tartalma sem azonos, mivel nem a teljes vállalati bérköltség, hanem csak a bruttó bérek változását jelzi. 
Adalékok a külföldi vállalatok magyarországi szerepének a megítéléséhez

\begin{tabular}{|c|c|c|c|c|c|c|}
\hline & (1) & (2) & (3) & (4) & (5) & (6) \\
\hline & $\begin{array}{c}F \text { bér, 2008-ban } \\
\text { átlagbér }=100\end{array}$ & $\begin{array}{l}\text { Bérem } \\
2008-\end{array}$ & $\begin{array}{l}\text { dés euróban, } \\
2008=100\end{array}$ & $\begin{array}{c}F \text { bér, 2016-ban } \\
\text { átlagbér }=100\end{array}$ & \multicolumn{2}{|c|}{$\begin{array}{c}F \text { részarány } \\
\text { a foglalkoztatásban, } \%\end{array}$} \\
\hline & 2008 & F & $\begin{array}{l}\text { ljes verseny- } \\
\text { szektor }\end{array}$ & 2016 & 2008 & 2016 \\
\hline Észtország & 122,8 & 134,2 & 129,6 & 127,1 & 22,4 & 22,1 \\
\hline $\begin{array}{l}\text { Spanyolor- } \\
\text { szág }\end{array}$ & 153,3 & 112,1 & 101,1 & 170,0 & 9,1 & 12,8 \\
\hline $\begin{array}{l}\text { Franciaor- } \\
\text { szág }\end{array}$ & 138,4 & 116,4 & 105,3 & 153,0 & 12,9 & 11,5 \\
\hline $\begin{array}{l}\text { Horvátor- } \\
\text { szág }\end{array}$ & 146,3 & 115,1 & 106,5 & 158,2 & 10,2 & 13,0 \\
\hline Olaszország & 197,5 & 116,7 & 114,6 & 201,1 & 7,4 & 8,4 \\
\hline Lettország & 159,8 & 114,6 & 115,1 & 159,2 & 15,6 & 19,9 \\
\hline Litvánia & 165,6 & 124,0 & 122,9 & 167,1 & 12,4 & 15,7 \\
\hline $\begin{array}{l}\text { Magyaror- } \\
\text { szág }\end{array}$ & 173,6 & 109,7 & 107,7 & 176,9 & 23,7 & 25,7 \\
\hline Hollandia & 163,8 & 113,7 & 113,5 & 164,0 & 14,0 & 17,3 \\
\hline Ausztria & 138,3 & 116,9 & 117,9 & 137,1 & 18,6 & 20,4 \\
\hline $\begin{array}{l}\text { Lengyelor- } \\
\text { szág }\end{array}$ & 178,7 & 106,6 & 108,6 & 175,4 & 14,0 & 18,3 \\
\hline Portugália & 178,7 & 103,8 & 108,4 & 171,1 & 10,2 & 13,1 \\
\hline Románia & 165,4 & 126,9 & 136,6 & 153,7 & 22,2 & 27,6 \\
\hline Szlovénia & 129,7 & 112,0 & 112,2 & 129,5 & 12,0 & 22,1 \\
\hline Szlovákia* & 168,6 & 146,9 & 103,3 & 173,7 & 32,6 & 28,5 \\
\hline Finnország & 125,7 & 146,9 & 103,3 & 131,7 & 16,1 & 16,5 \\
\hline Svédország & 122,1 & 115,4 & 110,1 & 127,4 & 22,5 & 21,0 \\
\hline $\begin{array}{l}\text { Nagy-Bri- } \\
\text { tannia }\end{array}$ & 135,4 & 124,8 & 119,6 & 147,2 & 18,1 & 19,0 \\
\hline
\end{tabular}

* Szlovákiára a 2008-as adat helyett a 2010-es adatot, Németország esetében pedig a 2016. évi adat helyett a 2015. évi adatot használtuk.

Forrás: Saját számítások az Eurostat Structural Business Statistics alapján.

Mint az 1. táblázatból látható, az EU-24-ben és ezen belül a tagországok többségében a külföldi vállalatok egy alkalmazottra jutó bérköltségszintje már 2008-ban a nemzetgazdasági átlag 120-200 százalékán állt, lásd (1) oszlop, 2008-2016 között pedig gyorsabban növekedett, mint a nemzetgazdasági átlag. Ennek következtében 2016-ra a bérköltségkülönbség tovább nőtt (4). A külföldi vállalatok részaránya is 
emelkedett a foglalkoztatásban az országok többségében, lásd (5) és (6) oszlop, ezen belül valamennyi visegrádi ország és Románia esetében.

A következőkben a fent említett hatásokat számszerüsítjük annak érdekében, hogy megállapíthassuk, mekkora volt a külföldi vállalatok szerepe a teljes vállalati szektor átlagos bérszintjének a változásában az egyes országokban. Ehhez egy standard dekompozíciós eljárást alkalmazunk, a következőképpen:

2. képlet

$$
\frac{w_{1}^{T}-w_{0}^{T}}{w_{0}^{T}}=\underbrace{\frac{\left(\alpha_{1} w_{1}^{F}-\alpha_{0} w_{0}^{F}\right)}{w_{0}^{T}}}_{\text {F szektor teljes hozzájárul. }}+\underbrace{\frac{\left.\left(1-\alpha_{1}\right) w_{1}^{D}-\left(1-\alpha_{0}\right) w_{0}^{D}\right)}{w_{0}^{T}}}_{\text {Dszektor teljes hozzájárul }} .
$$

3. képlet

$=\underbrace{\frac{\alpha_{0}\left(w_{1}^{F}-w_{0}^{F}\right)}{w_{0}^{T}}}_{F: \text { bér-hozzájárul. }}+\underbrace{\frac{\left(\alpha_{1}-\alpha_{0} w_{1}^{F}\right.}{w_{0}^{T}}}_{F \text { : létszám hozzájárul. }}+\underbrace{\frac{\left(1-\alpha_{0}\right)\left(w_{1}^{D}-w_{0}^{D}\right)}{w_{0}^{T}}}_{D \text { : bér-hozzájárul. }}+\underbrace{\frac{\left(\alpha_{0}-\alpha_{1} w_{1}^{D}\right.}{w_{0}^{T}}}_{\text {D: létszám hozzájárul. }}$

\section{Ahol:}

$T$ : nemzetgazdaság, $F$ : külföldi vállalatok, $D$ : helyi tulajdonú vállalatok

Kezdő és záró időpont: 0 és 1

Bérköltség: $W$

Létszám: $L$

Átlagbér: $w=W / L$

Teljes bérköltség felbontása: $W^{T}=W^{F}+W^{D}$

Teljes létszám felbontása: $L^{T}=L^{F}+L^{D}$

Átlagbér felbontása: $w^{T}=\alpha^{*} L^{F}+(1-\alpha)^{*} L^{D}$

A külföldi vállalatoknál foglalkoztatottak súlya: $\alpha=L^{F} / L^{T}$, a belföldieké $(1-\alpha)$

A 2. képlet alapján megállapíthatjuk, hogy milyen mértékben járult hozzá a külföldi $(F)$ és a belföldi $(D)$ vállalati szektor az átlagos vállalati bérszint változásához a vizsgált időszakban, egyrészt a béremelkedésnek az átlagtól való eltérése, másrészt a teljes foglalkoztatott létszámban betöltött részesedésének a változása következtében. A 3. képlet ezt a teljes hozzájárulást bontja fel a bérváltozás és a létszámváltozás (szerkezeti) hatásra. Az első tag azt jelzi, mekkora lett volna a külföldi vállalatok (F) hozzájárulása a teljes vállalati szektor bérváltozásához, ha a részarányuk nem 
változott volna. A második tag azt, mekkora lett volna ez a hozzájárulás, ha a külföldi vállalatok bérköltsége nem változott volna, hanem csupán a magasabb bérú külföldi vállalatok részaránya nőtt volna a foglalkoztatásban. A harmadik és a negyedik tag pedig ugyanezt mutatja a belföldi tulajdonú vállalatok $(D)$ vonatkozásában. Mivel a képlet elemei additívak, az elemek tetszőlegesen csoportosíthatóak.

A 2. és a 3. képletből a százalékpontos hozzájárulás számítható ki. A 2. táblázat ennek a százalékos összetételét közli, mivel ezek az adatok talán plasztikusabban és egységesebben mutatják a hozzájárulást, kiküszöbölve ezzel az egyes országok közötti bérnövekedési különbségeket.

Mint a 2. táblázat mutatja, az EU-22 szintjén a külföldi vállalatok százalékos hozzájárulása (az euróban kifejezett) béremelkedéshez 2008-2016 között kerekítve 54 százalék volt, míg a belföldieké 46 százalék (a teljes béremelkedést 100 százaléknak tekintve). Ez nem különösebben jelentős eltérés, aminek az oka az, hogy a kép meglehetősen heterogén. A legmagasabb átlagbérekkel rendelkező országokban (például Dániában, Ausztriában, Svédországban, Finnországban), amelyekben az induló bérszintkülönbség is csekély volt (lásd az 1. táblázat 1. oszlopát), a belföldi vállalatok egy főre jutó bérköltsége nagyobb mértékben emelkedett, mint a külföldieké, amit az (amúgy magasabb béreket fizetö) külföldi vállalatok részarányának az enyhe emelkedése csak csekély mértékben kompenzált.

Ezzel szemben a visegrádi országokban, Szlovéniában és Horvátországban ennek az ellenkezöje történt: a külföldi vállalatok hozzájárulása a teljes béremelkedéshez meghaladja a 100 százalékot, miközben a belföldieké negatív volt. A belföldi vállalatok esetében a külföldi vállalatokétól egyébként is jócskán elmaradó béremelkedés hatását a létszámváltozás nemcsak elmosta, hanem a negatív tartományba is tolta. A V4 országok „bérfelzárkózásához” tehát lényegében kizárólag a külföldi vállalatok béremelkedése és részarány-növekedése járult hozzá - legalábbis ebben az időszakban -, a belföldieké egyértelmüen visszahúzta a béremelkedés mértékét. 


\section{A külföldi és belföldi vállalatok hozzájárulása a bérek nemzetgazdasági szintủ} változásához

\begin{tabular}{|c|c|c|c|c|c|c|c|}
\hline & \multicolumn{2}{|c|}{$\begin{array}{l}\text { Bérváltozás } \\
\text { hatása }\end{array}$} & \multicolumn{2}{|c|}{ Összetételhatás } & \multirow{2}{*}{$\begin{array}{c}\text { Külföldi } \\
\text { vállalati hatás } \\
\text { összesen }\end{array}$} & \multirow{2}{*}{$\begin{array}{c}\text { Belföldi } \\
\text { vállalati hatás } \\
\text { összesen }\end{array}$} & \multirow[b]{2}{*}{ Összesen } \\
\hline & $F$ & $D$ & $F$ & $D$ & & & \\
\hline EU-22 & 37,8 & 54,9 & 16,4 & $-9,1$ & 54,2 & 45,8 & 100 \\
\hline Bulgária & 23,0 & 70,4 & 12,0 & $-5,4$ & 35,0 & 65,0 & 100 \\
\hline Csehország & 95,4 & 0,2 & 8,8 & $-4,4$ & 104,2 & $-4,2$ & 100 \\
\hline Dánia & 10,1 & 80,5 & 38,8 & $-29,4$ & 48,9 & 51,1 & 100 \\
\hline Németország* & 54,1 & 57,8 & $-24,5$ & 12,6 & 29,6 & 70,4 & 100 \\
\hline Észtország & 31,8 & 68,7 & $-1,7$ & 1,2 & 30,0 & 70,0 & 100 \\
\hline Franciaország & 55,2 & 62,1 & $-44,2$ & 26,9 & 11,0 & 89,0 & 100 \\
\hline Horvátország & 34,7 & 34,4 & 73,1 & $-42,2$ & 107,8 & $-7,8$ & 100 \\
\hline Olaszország & 16,8 & 74,8 & 15,4 & $-7,0$ & 32,2 & 67,8 & 100 \\
\hline Lettország & 24,2 & 51,9 & 51,5 & $-27,6$ & 75,7 & 24,3 & 100 \\
\hline Litvánia & 21,6 & 64,6 & 28,9 & $-15,1$ & 50,5 & 49,5 & 100 \\
\hline Magyarország & 52,0 & 18,5 & 50,6 & $-21,0$ & 102,5 & $-2,5$ & 100 \\
\hline Hollandia & 23,3 & 55,7 & 44,6 & $-23,6$ & 67,9 & 32,1 & 100 \\
\hline Ausztria & 24,3 & 70,4 & 15,7 & $-10,4$ & 40,0 & 60,0 & 100 \\
\hline Lengyelország & 19,2 & 30,5 & 95,6 & $-45,3$ & 114,8 & $-14,8$ & 100 \\
\hline Portugália & 8,3 & 61,0 & 64,2 & $-33,5$ & 72,4 & 27,6 & 100 \\
\hline Románia & 27,1 & 57,9 & 31,1 & $-16,1$ & 58,2 & 41,8 & 100 \\
\hline Szlovénia & 15,4 & 49,6 & 119,8 & $-84,8$ & 135,2 & $-35,2$ & 100 \\
\hline Szlovákia* & 44,4 & 19,8 & 60,3 & $-24,5$ & 104,7 & $-4,7$ & 100 \\
\hline Finnország & 30,8 & 67,7 & 5,4 & $-3,9$ & 36,2 & 63,8 & 100 \\
\hline Svédország & 34,8 & 68,3 & $-11,4$ & 8,3 & 23,4 & 76,6 & 100 \\
\hline Nagy-Britannia & 54,4 & 38,6 & 17,7 & $-10,7$ & 72,1 & 27,9 & 100 \\
\hline
\end{tabular}

* Szlovákiára a 2008-as adat helyett a 2010-es adatot, Németország esetében pedig a 2016. évi adat helyett a 2015. évi adatot használtuk.

Forrás: Saját számítások az Eurostat Structural Business Statistics alapján. 
Mindazonáltal van a vizsgált országok között néhány olyan, alapjában véve konzisztens és teljes adatsorral rendelkező ország, amely nagymértékben kilóg a fent leírt összefüggésekből. Leginkább Bulgária, ahol a belföldi vállalati bérek valamivel gyorsabban emelkedtek, mint a külföldiek (ez már az 1. táblázat 2. és 3. oszlopának sorából is kiolvasható volt). Ám rendkívül alacsony bérekröl van szó: az emelkedés következtében 2016-ra Bulgáriában a nemzetgazdasági vállalati átlagbér euróban számolva az EU-28 átlagának mindössze a 20 százalékára emelkedett (a 2008. évi 13,8 százalékról), a belföldi vállalatok átlagbére pedig az EU-átlag 11,9 százalékáról a 17,4 százalékára. Vásárlóerő-paritáson számolva a bolgár relatív bérek természetesen valamivel magasabbak, a bérleszakadás azonban még így is óriási, és a külföldi cégek bérelőnye (1. táblázat, 4. oszlop) továbbra is nagyon nagy. ${ }^{5}$ Hasonló történhetett Romániában is, kissé magasabb, Portugáliában pedig jóval magasabb bérszint mellett (Görögország és Spanyolország adatai sajnos hiányosak és/vagy a nagymértékủ éves ingadozások miatt megkérdőjelezhetők az adatbázisban).

Visszatérve a V4-országok bérfelzárkózásához, megkockáztatható, hogy a külföldi vállalatok szerepe még nagyobb, mint közvetlen, számszerúsíthető hatásuk. Feltételezhető ugyanis, hogy a külföldi vállalatok magasabb bérszintje és munkaerőelszívó hatása a belföldi cégeket is nagyobb béremelésre kényszeríthette, mint amilyet e nélkül vállaltak volna. Ezt a hatást nyilván nem lehet számszerűsíteni, csak megalapozottan feltételezni. Ameddig a munkaerő bőségesen rendelkezésre állt, azaz 2015-2016-ig, ez az elszívó hatás jórészt csak a munkaerő minőségére vonatkozott: a külföldi vállalatok a magasabb bérek révén a legjobb munkaerőt tudták megszerezni (igaz, maguk is képezték és továbbképezték őket). A magasabb színvonalú, fejlettebb technológia, szervezés és egyéb tényezők mellett ez is hozzájárult a magasabb termelékenységhez (Soós K. A., 2019). Azóta azonban a munkaerő-hiányos környezetben ez az elszívó hatás kifejezetten mennyiségivé vált, megnehezítve a belföldi cégek hozzájutását a munkaeröhöz.

Ez a helyzet súlyos gazdaságstratégiai dilemmát vet fel. A külföldi vállalatok részarányának a növekedése makroszinten növeli a nemzetgazdasági átlagbéreket, hajtja előre a bérfelzárkóztatást, ami kívánatos jelenség (számos jel szerint kissé még a munkaerő elvándorlását is fékezi). Hosszabb távon a bérverseny a belföldi tulajdonú vállalatokat is arra késztetheti, hogy megteremtsék a magasabb bérek fizetésének a gazdálkodási-technikai feltételeit. Ugyanakkor rövid és középtávon ez a hatás ellentmondásos, mivel az egyre súlyosabban munkaerőhiányos környezetben a

${ }^{5}$ A bolgár béradatok, különösösen a belföldi vállalatok bérstatisztikáinak megbízhatóságával kapcsolatban az adóelkerülés jelentős mértéke miatt megalapozott kétségeink lehetnek. 
bérek gyors emelkedése és a külföldi cégek munkaerö-elszívó hatása rontja a hazai vállalatok esetleges kitörési lehetőségeit.

\section{A külföldi nem pénzügyi vállalatok szerepe a termelékenység alakulásában}

Az egy alkalmazottra jutó hozzáadott érték, azaz a munkatermelékenység alakulása terén a külföldi vállalatoknak a nemzetgazdasági átlaghoz viszonyított elönye, illetve annak változása az EU-22 szintjén nem mutat egyértelmú trendet: az egy alkalmazottra jutó hozzáadott érték 2008 és 2016 között nagyjából azonos mértékben emelkedett, mint a teljes vállalati átlag.

Ezen belül azonban az egyes országok két vizsgált vállalati csoportja a nemzetközi gazdasági válság sokkjára a termelés és a foglalkoztatás terén nagyon különbözőképpen reagált, és azt követően is eltérő módon ment végbe a helyreállítás az egyes vállalati szegmensekben. 2009-ben kivétel nélkül valamennyi vizsgált országban mind a hozzáadott érték termelése, mind a foglalkoztatottak száma csökkent a vállalati szektorban, a külföldi és belföldi vállalatoknál egyaránt, csak a csökkenés mértéke volt különbözö, mind az egyes vállalati szegmensek, mind a hozzáadott érték és a foglalkoztatás terén. ${ }^{6}$ Mivel itt egy négytényezős mátrixnak a változásáról van szó (külföldi-belföldi, termelés-foglalkoztatás), a kimenet nagyon eltérő volt.

A válság legmélyebb pontját jelentő 2009 után a helyreállítás sem egyforma mértékben ment végbe. Spanyolországban például még 2016-ban is alacsonyabb volt a teljes vállalati szintủ hozzáadott érték, mint 2009-ben, miközben a külföldi cégek hozzáadott értéke határozottan nőtt. A foglalkoztatott létszám a belföldi cégeknél azonban ehhez kevéssé igazodott, ebből származik a 6. ábrán látható kiugró növekedés a külföldi vállalatok termelékenységi előnye terén a vizsgált időszakban. Hasonló a helyzet Lettországban is. Finnországban 2015-re a nemzetgazdasági szintủ vállalati termelékenység elérte ugyan a 2008. évi szintet, ebben azonban elsősorban, bár nem kizárólag, a külföldi cégek hozzáadottérték-termelésének a gyors növekedése játszott szerepet (miközben a Nokia, a finn gazdaság zászlóshajója továbbra is gyengélkedik).

\footnotetext{
${ }^{6}$ Figyelemre méltó módon a vállalati hozzáadott érték még Lengyelországban is csökkent, amely a 2009-es pénzügyi válságot az EU-tagországok közül egyedüliként élte túl gazdasági visszaesés nélkül. Ez arra mutat, hogy a lengyel GDP növekedése 2009-ben nem a vállalati szektorból származott, hanem főként költségvetési forrásból táplálkozott. Erre utal az is, hogy a lengyel államháztartás hiánya 2009-ben az előző évi 3,6 százalékról 7,3 százalékra emelkedett a GDP arányában, miközben a GDP 2,8 százalékkal nőtt.
} 


\section{A külföldi vállalatok egy alkalmazottra jutó hozzáadott értéke a nemzetgazdasági vállalati átlaghoz képest, 2008-2016}

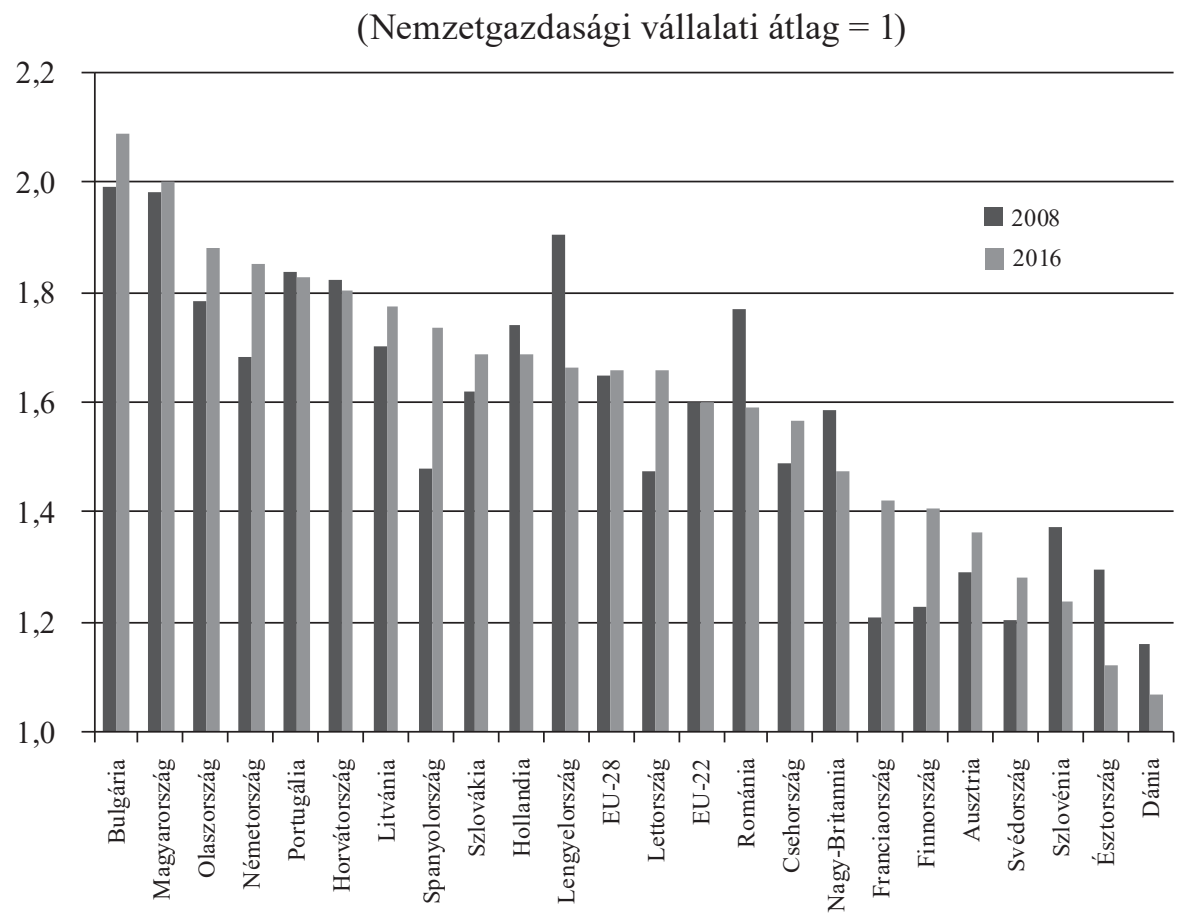

Megjegyzés: Adathiány miatt a korábban említett négy országon kívül nem szerepel Belgium és Görögország sem.

Forrás: Saját számítások az Eurostat Structural Business Statistics alapján.

Ami a külföldi cégeknek a V4 országokban mért relatív termelékenységi előnyét illeti, e téren nem látható olyan egységes kép, mint amit a relatív béreknél tapasztaltunk. Bulgária után továbbra is Magyarországon a legnagyobb a külföldi vállalatok termelékenységi előnye a nemzetgazdasági vállalati átlaghoz képest (kétszeres), ez a vizsgált időszakban alig változott. Az egy-két százalékpontos növekedés Szlovákiában (1,7-szeresre) és Csehországban (1,6-szorosra) szintén stagnálásnak tekinthető. Lengyelországban az ellenkezöje történt: noha a válság után mind a külföldi, mind a belföldi vállalatok hozzáadott értéke és foglalkoztatása emelkedett, az adatok szerint a külföldi vállalatok nagyobb mértékben emelték a létszámot, mint amit a hoz- 
záadott érték növekedése indokolt volna. Ez az adatsor akár némi kételyre is adhat okot, mindenesetre további vizsgálatot igényel.

Hangsúlyozni kell, hogy a külföldi tulajdonú vállalatok szükségképpen termelékenyebbek és magasabb bérszint jellemzi öket, mint a belföldiek. Nem azért, mert „külföldiek”, hanem azért, mert azok a vállalatok, amelyek külföldi piacokra lépnek, a küldő országban is valamilyen vállalatspecifikus tudással, technológiával, know-how-val, esetleg marketing- és értékesítési stratégiával vagy márkanévvel rendelkeznek, amelyekkel a befogadó ország heterogén vállalati szektorának az átlaga nem. A hazai gazdaságban ugyanis mindenféle vállalkozás megtalálható, köztük alacsony termelékenységủ cégek is, miközben a külföldi vállalatok egyfajta válogatott csapatot képeznek, amelyek a küldő országokban is a legversenyképesebbnek számítanak. Így történhet meg, hogy akár a dán, akár a holland vállalati szektorban valamivel magasabb a külföldi vállalatok termelékenysége a hazaiak átlagánál. A V4 országokban ez a különbség különösen nagy (1,6-2-szeres), és kimagaslóan nagy Magyarországon, ami a belföldi tulajdonú vállalatok különösen gyenge relatív versenyképességével magyarázható.

Kétségtelen, hogy a termelékenységi különbségeket a vállalati méret is befolyásolja, ám erről ez az adatsor nem ad információt. Azt tudjuk csak, hogy a külföldi vállalatok átlagos foglalkoztatotti létszáma az EU-24-ben 50-150 fö között ingadozik, miközben a belföldiek átlaga minden országban 10 alatt van. Az utóbbi mögött nagyon heterogén vállalati méreteloszlás húzódhat meg, a belföldi tulajdonú szegmensben mikro-, kis-, közép- és nagyvállalatok egyaránt müködnek. Mindenesetre a szétaprózottabb belföldi vállalati méretszerkezet fontos magyarázó tényező lehet a különböző tulajdonú vállalatok közötti termelékenységi különbségekre. Ugyanakkor nem magyarázza a termelékenységi különbségek országok közötti eltéréseit.

\section{Következtetések}

Az SBS adatbázis alapján készített számítások azt mutatják, hogy a külföldi vállalatok jelenléte növekvő mértékben járul hozzá a kelet-közép-európai országok gazdasági növekedéséhez, a hozzáadottérték-termeléshez és a GDP-hez. A magyar gazdaság esetében ez a hozzájárulás különösen számottevő: 2016-ban a GDP körülbelül 30 százalékát, a vállalati szektor hozzáadott értékének pedig több mint a felét a külföldi tulajdonú vállalatok állították elö, s részarányuk továbbra is növekvő. $A$ 
teljes magyar bruttó hazai termék (beleértve az állami szektorhoz kötődő nem piaci tevékenységeket is) közel egyharmadát tehát a külföldi vállalatok termelik meg.

A külföldi vállalatok súlya a termelésben és a foglalkoztatásban az EUtagországok többségében is emelkedő tendenciát mutat, ez azonban EU-szinten jóval szerényebb, mint a felzárkózók körében. A fejlettebb országokban a külföldi cégek részesedése jellemzően alacsonyabb, ugyanakkor a statisztikai összefüggés a fejlettség (GDP/fö) és a külföldi vállalatok részesedése között gyenge és nem szignifikáns, mivel a kép nagyon heterogén.

A V4 országokban, és különösen Magyarországon zajló dependens fejlödési útnak előnyei és hátrányai egyaránt vannak. Lehet kárhoztatni a külföldi vállalatokat azért, mert az alacsonyabb bérszintű országokba a globális termelési lánc alacsonyabb hozzáadott értéket termelő elemeit telepítik. A globális termelési lánc három fázisra osztható. (1) a termelést megelőző kutatási, tervezési, stratégiai fázis, (2) a termelési fázis, (3) marketing, kommunikáció, értékesítési fázis. A legmagasabb hozzáadott érték kétségtelenül az első és a harmadik fázisban keletkezik, hiszen az értékesító cég itt tudja érvényesíteni vállalatspecifikus tudását, know-how-ját és/ vagy piaci erejét, a trade mark értékét. A középső, termelési fázisban a hozzáadott érték szerényebb. Kétségtelen, hogy a multinacionális vállalatok a felzárkózó országokba jellemzően a termelési fázist helyezik ki (bár van példa az első és a harmadik fázis egyes elemeinek a kitelepítésére is). Ebből ered a pejoratívan használt „összeszerelő gazdaság" kifejezés, amely lekicsinyli a külföldi vállalatok jelentőségét a hozzáadott érték termelésében.

Mindazonáltal a külföldi vállalatok termelékenysége így is 1,5-2-szeresen meghaladja a nemzetgazdasági vállalati átlagot a V4-országokban, és nagyjából a belföldi vállalatok 2-3-szorosát teszi ki (a legnagyobb különbség Magyarországon mutatkozik). Szakszerütlen és történelmietlen lenne azt állítani, hogy amennyiben nem lennének külföldi vállalatok a magyar gazdaságban, akkor a vizsgált gazdasági mutatók kizárólag a belföldi vállalatok által meghatározott, lényegesen alacsonyabb szinten állnának. Az azonban minden további nélkül állítható, hogy a külföldiek jelenléte nélkül mind a termelékenység, mind a GDP és az átlagos bérszínvonal számottevően alacsonyabb lenne. Természetesen törekedni kell arra, hogy a külföldi vállalatok a globális termelési lánc minél magasabb hozzáadottérték-tartalmú fázisait allokálják. Tisztában kell lenni azonban azzal, hogy ebben az esetben tovább nőne a külföldi vállalatok súlya a befogadó gazdaságok GDP-jében és foglalkoztatásában, ami a jelenlegi munkaerő-hiányos környezetben a képzett munkaerőt még nagyobb mértékben szívná el a belföldi cégektől. 
Lehet kárhoztatni a külföldi vállalatokat azért is, mert a magasabb munkatermelékenységből fakadó előnyöket a bérekben nem teljes mértékben érvényesítik. Bár ez bonyolultabb kérdés, mivel a befektetett tőkének is meg kell térülnie (az SBS adatokból tőketermelékenységet nem lehet számolni). Az azonban bizonyos, hogy a külföldi vállalatok előnye a munkatermelékenységben lényegesen nagyobb, mint a bérszínvonalban (Magyarország esetében a munkatermelékenység a belföldi vállalatok háromszorosa, a bérszínvonal mintegy a kétszerese).

Mindazonáltal a bemutatott számítások alapján megállapítható, hogy 2008 és 2016 között kizárólag a külföldi vállalatok járultak hozzá a V4 országokban a bérfelzárkózásához, miközben a belföldi cégek béremelése jócskán elmaradt a teljes vállalati szektor átlagos béremelkedésétől. A számítások azt jelzik, hogy a külföldi vállalatok nélkül a V4 országokban, és különösen Magyarországon 2008 és 2016 között lényegében nem lett volna bérfelzárkózás. A külföldi vállalatok magasabb bérszínvonala a képzettebb munkaerő díjazását is tükrözi. Ezt a külföldi cégek a magasabb bérek vonzereje mellett a saját képzéssel érik el. A vállalati képzés révén a külföldi cégek olyan munkaerőpiaci előnyhöz jutnak, amellyel a belföldi vállalatok elvétve rendelkeznek. Ez a kiszorítási hatás a munkaerő-hiányos környezetben feltehetőleg erősödni fog, sőt minden valószínüség szerint az elmúlt két évben is erősödött. ${ }^{7}$

Ez az ellentmondásos helyzet súlyos gazdaságstratégiai dilemmát vet fel Magyarországon (is). Egyfelöl, a külföldi vállalatok rövid- és középtávon döntő mértékben járulnak hozzá a gazdaság növekedéséhez, az átlagos termelékenység emelkedéséhez és a bérfelzárkózáshoz, azaz a makroszintű indikátorok javulásához. Ennyiben a jelenlegi, a külföldi tőke bevonzására fókuszáló gazdaságstratégia igazolható is. Másfelöl a külföldi vállalatok növekvő térnyerése folyamatosan csökkenti a gazdaságban és a foglalkoztatásban a belföldi cégek súlyát, amelyek hozzáadottértéktermelési képessége nem tud lépést tartani a nemzetgazdasági vállalati átlaggal. Ez pedig közép- és hosszabb távon növeli a gazdaság függőségét a külföldi befektetésektől. Ennek az elemzésnek nem volt célja a hazai tulajdonú vállalatok felzárkózási esélyeinek mikroszintủ vizsgálata (erről lásd bővebben: Szalavetz, 2015), csupán a gazdaságszerkezeti átrendeződések következményeinek a makroszintű elemzésére fókuszált. Mindenesetre a magyar gazdaság legfőbb problémája nem az, hogy a külföldi vállalatok nem a legmagasabb hozzáadott értéket létrehozó termelési fázisokat

7 Az SBS adatok jelenleg csak 2016-ig állnak rendelkezésre, holott a V4 országok bérfelzárkózása az elmúlt két évben gyorsult fel. Tanulságos lesz ezt a számítást megismételni a 2017-2018-as vállalati béradatok alapján. 
hozzák Magyarországra, vagyis hogy Magyarország „összeszerelö üzem” lenne, ami a relatíve alacsony bérszínvonalon alapul. Az alacsony bérek - legalábbis a legutóbbi időkig - éppenséggel a belföldi vállalatok túlélési esélyeit támogatták, illetve az összefüggést megfordítva: a magyarországi bérszínvonalat a belföldi vállalatok alacsony termelékenységi szintje határozta meg.

A kulcskérdés tehát jelenleg a magasan képzett munkaerő rendelkezésre állása és az átlagbérek emelkedése a belföldi vállalati szektorban. Ha tehát a gazdaságpolitika a belföldi tulajdonú vállalatok felzárkózását is támogatni kívánja, akkor a legmodernebb technológiákat alkalmazni tudó, a szakmát széles spektrumban átlátni képes munkaerő képzésére szolgáló állami (szak)képzési rendszer fejlesztésére kell koncentrálnia.

\section{Hivatkozások}

Antalóczy Katalin - Sass Magdolna [2003]: Müködőtőke-befektetések és a külkereskedelem modernizációja - nemzetközi kitekintés és hazai tapasztalatok. Külgazdaság, 47. évf., 12. szám.

Antalóczy Katalin - Sass Magdolna [2014]: Tükör által homályosan: a külföldi közvetlentőkebefektetések statisztikai adatainak tartalmáról. Külgazdaság, 58. évf., 7-8. szám.

Bijsterbosch, M. - Kolasa, M. [2009]: FDI and productivity convergence in Central ad Eastern Europe. An industry-level investigation. ECB Working Paper Series, No. 992.

Boda György - Révész Tamás - Losonci Dávid - Fülöp Zoltán [2019]: A növekedési ütem és a foglalkoztatás növelésének lehetőségeiről. Közgazdasági Szemle, 46. évf., 4. szám, 376-417. o.

Borensztein, E. - De Gregorio, J. - Lee, J-W. [1995]: How Does Foreign Direct Investment Affect Economic Growth? NBER Working Paper Series, No. 5057.

Éltetö Andrea - Antalóczy Katalin [2017]: FDI Promotion of the Visegrad Countries in the Era of Global Value Chains. MTA KRTK, Világgazdasági Intézet, Working Paper, No. 229.

Gál Zoltán - Sass Magdolna - Juhász Bálint [2016]: A külföldi közvetlentőke-befektetések és a válság hatása a fogadó gazdaságra: a visegrádi országok egyes szolgáltató ágazatainak vizsgálata. Külgazdaság, 60. évf., 7-8. szám.

Gorodnichenko, Y. - Svejnar, J. - Terrel, K. [2007]: When does FDI have Positive Spillovers? Evidence from 17 Emerging Market Economies. IZA Discusson Paper, No. 3079.

Hunya Gábor [2001]: Uneven competitiveness of industries in the wake of foreign penetration of advanced economies in transition. Transnational Corporations, Vol. 10., No. 2., 35-66. o.

Javorcik, B. S. [2004]: Does Foreign Direct Investment Increase the Productivity of Domestic Firms? In Search of Spillovers Through Backward Linkages. The American Economic Review, Vol. 94., No. 3., 605-627. o.

Kalotay Kálmán - Hunya Gábor [2000]: Privatisation and FDI in Central and Eastern Europe. Transnational Corporations, Vol. 9., No. 1., 39-66. o.

Lipsey, R. E. [2006]: Measuring the impacts of FDI in Central and Eastern Europe. NBER Working Paper Series, 12808 .

Oblath Gábor [2017]: FDI flows and reinvested earnings: statistical measurement, perceptions and economic interpretation. Hungarian Statistical Review, Special Number 21., 48-77. o. Letölthető: http://www.ksh.hu/statszemle_archive/2017/2017_K21/2017_K21_048.pdf 
OECD [2019]: Addressing the Tax Challenges of the Digitalisation of the Economy. Public Consultation Document. OECD/G20 Base Erosion and Profit Shifting Project. Letölthető: https://www.oecd. $\mathrm{org} / \mathrm{tax} / \mathrm{beps} /$ public-consultation-document-addressing-the-tax-challenges-of-the-digitalisationof-the-economy.pdf

Mihályi Péter [1998]: A magyar privatizáció krónikája. Közgazdasági és Jogi Könyvkiadó, Budapest.

Mihályi Péter [2010]: A magyar privatizáció enciklopédiája. Pannon Egyetemi Könyvkiadó-MTA Közgazdaságtudományi Intézet, Budapest, 2010, I-II. kötet, 992 + 664 oldal

Pavlinek, P. [2017]: Dependent Growth: Foreign Investment and the Development of the Automotive Industry in East-Central Europe. Springer International Publishing.

Sinn, H-W. - Weichenrieder, A. J. [1997]: Foreign Direct Investment, Political Resentment and the Privatization Process in Eastern Europe. Economic Policy, Vol. 12., No. 24., 177-210. o.

Soós Károly Attila [2018]: Keresetek és képzettségi prémium a külföldi tulajdonú, exportáló feldolgozóipari vállalatoknál Magyarországon. Külgazdaság, 62. évf., 5-6. szám, 3-33. o.

Stančik, J. [2008]: FDI Spillovers in the Czech Republic: Takeovers vs. Greenfields. European Economy, Economic Papers 369/March.

Szalavetz Andrea [2015]: Szakosodás és feljebb lépés a multinacionális vállalatok globális értékláncain belül. Magyarországi feldolgozóipari leányvállalatok tapasztalatai. Akadémiai doktori értekezés. Letölthetö: http://real-d.mtak.hu/861/7/dc_1027_15_doktori_mu.pdf

Szalavetz Andrea [2017]: Upgrading and value capture in global value chains in Hungary: More complex than what the smile curve suggests. In: Szent-Iványi, B. (ed.): Foreign direct investment in Central and Eastern Europe: Post-crisis perspectives. Palgrave Macmillan, 127-150. o.

Vakhal Péter [2017]: Magyarország elhelyezkedése a globális érték- és termelési láncban. Készült a Költségvetési Tanács számára. Budapest, Kopint-Tárki.

Letölthetö: https://www.parlament.hu/documents/126660/1249496/Magyarorsz\%C3\%A1g+elhe lyezked $\% \mathrm{C} 3 \% \mathrm{~A} 9 \mathrm{se}+\mathrm{a}+\mathrm{glob} \% \mathrm{C} 3 \% \mathrm{~A} 11$ is $+\% \mathrm{C} 3 \% \mathrm{~A} 9 \mathrm{rt} \% \mathrm{C} 3 \% \mathrm{~A} 9 \mathrm{kl} \% \mathrm{C} 3 \% \mathrm{~A} 1$ ncban.pdf $/ 6 \mathrm{~d} 88 \mathrm{~d} 39 \mathrm{e}-$ 51ee-49f9-78b8-f79c6a2fe949

Voszka Éva [1996]: A tulajdonváltás felemás sikeréve. Közgazdasági Szemle, 43. évf., 5. szám, 385402. o. 